9 Goldberg DP. Manual of the general health questionnaire. Windsor: NFER Publishing Company, 1979 .

10 Neese R, Corli T, Curtis G, Kleinman P. Pretreatment nausea in cancer chemotherapy: a conditioned response? Psychosom Med 1980;58:277-99.

11 Hughson AVM, Cooper AF, McArdle CS, Russell AR, Smith DC. Psychiatric morbidity in disease-free survivors following radiotherapy and adjuvant chemotherapy for breast cancer: a 2-year follow-up study. Br $\mathcal{F}$ Surg 1980;67:370.

12 Palmer BV, Walsh GA, McKinna JA, Greening WP. Adjuvant chemotherapy for breast cancer: side-effects and quality of life. Br Med $\mathcal{J} 1980 ; 281: 1594-7$.

13 Maguire GP, Tait A, Brooke M, Thomas C, Howat JMT, Sellwood R. Psychiatric morbidity and physical toxicity associated with adjuvant chemotherapy after mastectomy. $\mathrm{Br} \mathrm{Med} \mathcal{J}$ 1980;281:1179-80.

14 Maguire P. Psychiatric morbidity and physical toxicity associated with adjuvant chemotherapy. BrMed f 1980;281:1641.

15 Maguire P, Tait A, Brooke M, Thomas C, Sellwood R. Effect of counselling on the psychiatric morbidity associated with mastectomy. Br Med $\mathcal{F}$ 1980;281:1454-6.

16 Howell A, George WD, Crowther D, et al. Controlled trial of adjuvant chemotherapy with cyclophosphamide, methotrexate, and fluorouracil for breast cancer. Lancet 1984;ii:307-11.

17 Consensus conference. Adjuvant chemotherapy for breast cancer. FAMA 1985;254:3461-3.
18 Meyerowitz BE, Sparks FC, Spears IK. Adjuvant chemotherapy for breast carcinoma. Psychosocial implications. Cancer 1979;43:1613-8.

19 Meyerowitz BE, Watkins IK, Sparks FC. Psychosocial implications of adjuvant chemotherapy. A two-year follow-up. Cancer 1983;52:1541-5.

20 Silberfarb PM, Maurer LH, Crouthamel C. Psychosocial aspects of neoplastic disease. I. Functional status of breast cancer patients during different treatment regimens. Am $\mathcal{J}$ Psychiatry 1980;137:450-5.

21 Baum M, Priestman T, West RR, Jones EM. A comparison of subjective responses in a trial comparing endocrine with cytotoxic treatment in advanced carcinoma of the breast. Eur $\mathcal{f}$ Cancer 1980; suppl 1:223-6.

22 Morrow GR, Morrell C. Behavioral treatment for the anticipatory nausea and vomiting induced by cancer chemotherapy. $N$ Engl 7 Med 1982;307:1476-80.

23 Redd WH. Control of nausea and vomiting in chemotherapy patients. Postgrad Med 1984;75: $105-13$.

24 Bonadonna G, Valagussa $\mathrm{P}$, Rossi A, et al. Ten-year experience with CMF-based adjuvant chemotherapy in resectable breast cancer. Breast Cancer Res Treat 1985;5:95-115.

\title{
Childhood respiratory infection and adult chronic bronchitis in England and Wales
}

\author{
D J P BARKER, C OSMOND
}

\begin{abstract}
The high mortality from chronic bronchitis in England and Wales and the excess of urban over rural mortality are unexplained. On dividing England and Wales into 212 local authority areas a strong geographical relation was found between death rates from chronic bronchitis and emphysema in 1959-78 and infant mortality from bronchitis and pneumonia during 1921-5. It was concluded that this relation provided strong evidence of a direct causal link between acute lower respiratory infection in early childhood and chronic bronchitis in adult life. Regression analysis suggested that infection in early childhoood had a greater influence than cigarette smoking in determining the geographical distribution of chronic bronchitis. National time trends reflected the influence of both factors.
\end{abstract}

Chronic air pollution in adult life may be less important a cause of chronic bronchitis than previously supposed.

\section{Introduction}

Britain has a higher mortality from chronic bronchitis than any other country in western Europe. ${ }^{1}$ This cannot be explained by international differences in environmental influences such as cigarette smoking and atmospheric pollution, nor by differences in death certification practices. ${ }^{2}$ The excess of urban over rural mortality and morbidity from bronchitis, which is characteristic of Britain, is also unexplained.

Reid and others conjectured that respiratory disease in childhood was a cause of chronic bronchitis in later life.$^{46}$ Recent findings have shown that bronchiolitis, bronchitis, and pneumonia in infancy lead to persisting damage to the airways during childhood, with cough, wheeze, bronchial reactivity, and impaired ventilatory function. ${ }^{7} \cdot 10$ In the long term follow up of a national sample of British children

MRC Environmental Epidemiology Unit, University of Southampton, Southampton General Hospital, Southampton SO9 4XY D J P BARKER, PHD, FRCP, director and professor of clinical epidemiology C OSMOND, PHD, statistician

Correspondence to: Professor Barker. born in 1946 young adults who had had one or more lower respiratory infections before 2 years of age had a higher prevalence of chronic cough. ${ }^{112}$ There is, however, no direct evidence to link respiratory infection during childhood with clinically established chronic bronchitis in adult life.

We have examined the geographical relation between past infant death rates from lower respiratory tract infection and current adult mortality from chronic bronchitis in England and Wales. We have also analysed the time trends in mortality from chronic bronchitis over the past 40 years.

\section{Methods}

The Office of Population Censuses and Surveys made available extracts from all death certificates in England and Wales during 1959-78. Our previous analysis of these data in relation to past infant mortality was based on the 11 years $1968-78,{ }^{13}$ the period covered by the eighth revision of the International Classification of Diseases (ICD). For this analysis we added data on four selected causes of death during 1959-67. Mortality rates at ages 35-74 years were calculated for each sex and each local authority area grouped according to boundaries before 1974. For 1968-78 rates were based on data from the 1971 Census, while for 1959-67 data from the 1961 Census were used. Rates were expressed as standardised mortality ratios. We used published mortality rates ${ }^{14}$ for 1941-80 to analyse the time trends of chronic bronchitis and emphysema (ICD codes 106 b,c, 113 (5th revision); 501-502, 527 (6th revision); 501-502, 527.1 (7th revision); 490-492 (8th and 9th revisions)).

In England and Wales numbers of infant deaths by specific cause were published only from 1921, and this analysis is based on the years 1921-5. We divided causes of infant deaths into five groups using Woolf's classification ${ }^{15}$-congenital, bronchitis and pneumonia, infectious diseases, diarrhoea, and others.

We compared adult mortality (1959-78) with infant mortality (1921-5) in the four main geographical groups used by the Registrar General since 1911 - that is, county boroughs (larger towns), London boroughs, urban areas (metropolitan boroughs and urban districts) within counties, and rural areas. These groups divide England and Wales into 212 local authority areas, comprising 80 county boroughs, 15 London boroughs, 59 urban areas, and 58 rural areas. ${ }^{13}$

We used correlation coefficients, regression analysis, and scatter plots to examine the relation between different causes of adult and infant deaths. The coefficients are influenced by the numbers of deaths as well as by the strength of the relation. During 1921-5 there were 291082 infant deaths, 127796 in the first month of life (neonatal) and 163286 thereafter (postneonatal). Death was attributed to bronchitis and pneumonia in 61770 .

$\underline{\omega}$ 
Calculations of rates for bronchitis during 1959-78 for ages 35-74 years are based on 256470 deaths in men and 121157 deaths in women.

We have summarised trends in age specific mortality for bronchitis and lung cancer by a set of birth cohort (generation) values and period of death values. This method has been described ${ }^{16}$ Cohort values summarise the mortality experience of a generation, while period values summarise the experience of all age groups at one point in time. Each age specific rate contributes to both a cohort and a period value by reference to all other rates at that age. Cohort and period values are adjusted to give an average of unity and are similar to relative risks in having no units.

\section{Results}

Infant mortality in England and Wales during 1921-5 was 76/1000 births. Of these deaths, $16 / 1000$ births were attributed to bronchitis and pneumonia, with rates among boys of 19/1000 and among girls of 14/1000. Rates of bronchitis and pneumonia in the 212 local authority areas varied from two to 33/1000 births. They were highest in the county boroughs at 20/ 1000 and fell to 16 in the London boroughs, 15 in the urban areas, and 11 in the rural areas. Standardised mortality ratios for bronchitis among men aged 35-74 during 1968-78 ranged from 26 to 205 and among women from 27 to 292. Again standardised mortality ratios were highest in the county boroughs at 121 for men and 126 for women and fell to 113 for each sex in the London boroughs, 97 and 94 respectively in the urban areas, and 74 and 73 respectively in the rural areas.

During 1968-78 there were 25 causes of death for which more than 10000 deaths occurred in each sex or in the sex usually affected. ${ }^{17}{ }^{18}$ Table I shows the coefficients of correlation between infant mortality caused by bronchitis and pneumonia in the 212 local authority areas and the leading causes of death in both sexes at ages 35-74. In descending order the coefficients were 0.85 for bronchitis, 0.73 for chronic rheumatic heart disease, 0.71 for cancer of the stomach, 0.68 for ischaemic heart disease, and 0.56 for lung cancer. Table I also shows that infant deaths from bronchitis and pneumonia correlated more highly with adult bronchitis than did infant deaths in any of the other four cause groups. Among the infectious diseases only measles had a high correlation $(r=0 \cdot 77)$, the next highest $(r=0.29)$ being for whooping cough.

When infant respiratory mortality during $1921-5$ was correlated with the other causes of infant death the coefficients were lower than that with adult bronchitis during 1968-78 (table I). Similarly, when standardised mortality ratios for bronchitis during 1968-78 were correlated with those for the other causes of adult death the coefficients were lower than that with infant respiratory mortality during 1921-5 (table I). The strength of the relation was further emphasised by the low correlation $(r=0 \cdot 20)$ between infant respiratory mortality in $1921-5$ and mortality from bronchitis at all other ages during those same years.

Figures 1 and 2 show the close geographical relation between infant deaths from bronchitis and pneumonia and subsequent adult deaths from bronchitis in each sex. The statistical dependence is such that an increase among areas of 10 infant deaths per 1000 births corresponds with increases in standardised mortality ratios for bronchitis of 45 in men and 53 in women.

Table II shows correlations by sex and age group within the 212 areas. Rheumatic heart disease is included because it is known to be caused by respiratory borne infection in childhood, pneumococcal pneumonia because it is caused by adult respiratory infection. Lung cancer is associated with cigarette smoking, a known risk factor for bronchitis. The coefficients for bronchitis were consistently high in both sexes and each age group above 45 .

TABLE I-Correlation of causes of infant death (rates) during 1921-5 and of adult deaths (standardised mortality ratios) during 1968-78 in 212 geographical areas of England and Wales

\begin{tabular}{lcc}
\hline & $\begin{array}{c}\text { Infant mortality from } \\
\text { bronchitis and pneumonia } \\
1921-5\end{array}$ & $\begin{array}{c}\text { Adult mortality from } \\
\text { bronchitis } \\
1968-78\end{array}$ \\
\hline Bronchitis and pneumonia & Infant mortality 1921-5 & \\
Congenital & 1.00 & 0.85 \\
Diarrhoea & 0.60 & 0.53 \\
Infectious diseases & 0.78 & 0.74 \\
Other & 0.65 & 0.61 \\
& 0.65 & 0.55 \\
Bronchitis & & \\
Rheumatic heart disease & Adult morality 1968-78 & 1.00 \\
Stomach cancer & 0.85 & 0.78 \\
Ischaemic heart disease & 0.73 & 0.71 \\
Lung cancer & 0.71 & 0.63 \\
Pneumococcal pneumonia & 0.68 & 0.62 \\
& 0.56 & 0.34 \\
\hline
\end{tabular}

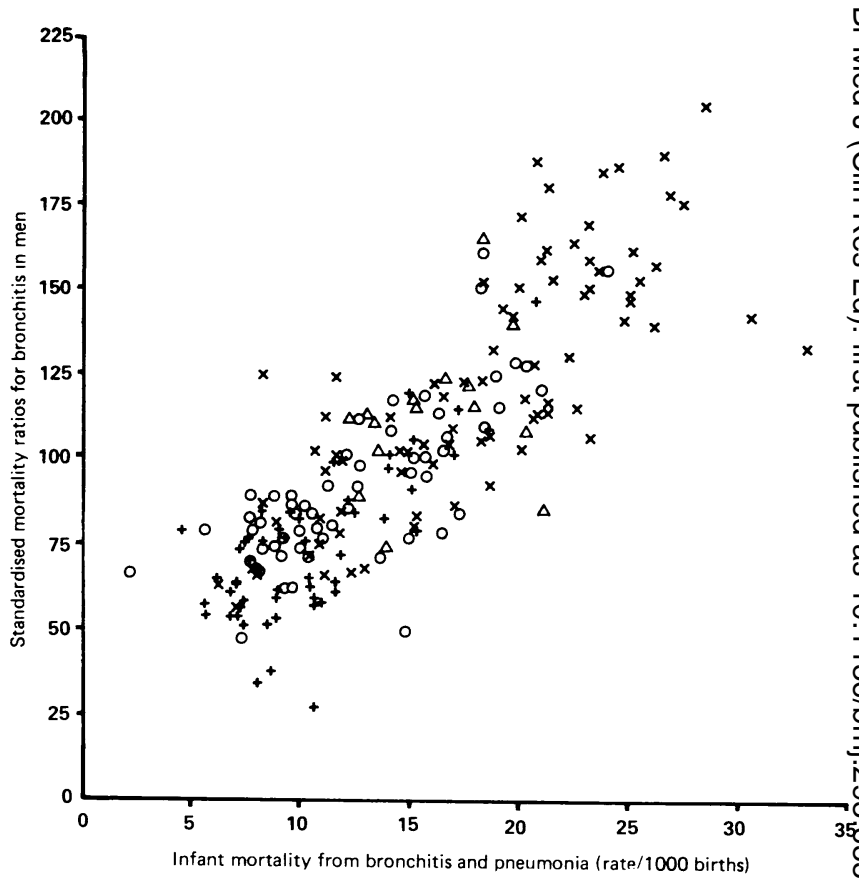

FIG 1-Standardised mortality ratios for chronic bronchitis in men aged 35-7z during 1968-78 and infant mortality from bronchitis and pneumonia per 1000 births in $1921-5$ in 212 areas of England and Wales. $x=$ County boroughs. $\triangle=$ London boroughs. $\mathrm{O}=$ Urban areas. $+=$ Rural areas.

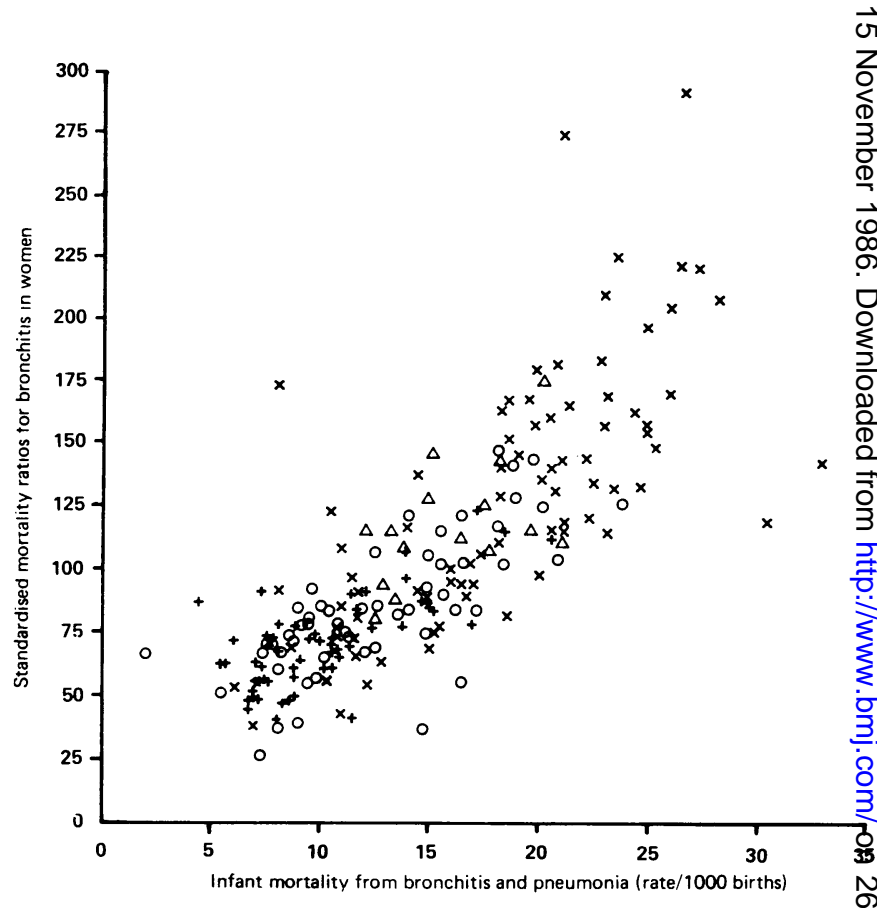

FIG 2-Standardised mortality ratios for chronic bronchitis in women aged 35during 1968-78 and infant mortality from bronchitis and pneumonia per 1000 births in 1921-5 in 212 areas of England and Wales. $x=$ County boroughs. $\triangle \nabla$ London boroughs. $\bigcirc=$ Urban areas. $+=$ Rural areas.

The lower values in the youngest age group may reflect the smaller number of deaths. Most coefficients for rheumatic heart disease, pneumococes pneumonia, and lung cancer were lower than those for bronchitis.

The coefficients for bronchitis and rheumatic heart disease varied litt among the three geographical groups-county boroughs and Londori boroughs, urban areas, and rural areas (table III). Those for pneumococco pneumonia, however, were negative among women in urban and rural areas. For lung cancer they were low among men in rural areas and zero or negati远 among women.

For deaths during the period 1959-67 the coefficients for chron bronchitis and rheumatic heart disease were again consistently high in the three geographical groups in either sex (table IV). Those for pneumococes 
BRITISH MEDICAL JOURNAL VOLUME 29315 NOVEMBER 1986

pneumonia were negative in rural areas, while those for lung cancer were positive only among men in county boroughs.

Table $\mathrm{V}$ shows the correlations between standardised mortality ratios for bronchitis during 1968-78 and those for rheumatic heart disease, pneumococcal pneumonia, and lung cancer. For rheumatic heart disease correlations were consistently high in each geographical group and in either sex. They were, however, lower than those with infant respiratory mortality.

The statistical dependence of the geographical distribution of chronic bronchitis on geographical variations in past infant deaths from bronchitis and pneumonia and variations in smoking, as indicated by current deaths from lung cancer, is described by the regression equations: standardised mortality ratio for bronchitis in men $=0.60$ infant death rate +0.41 standardised mortality ratio for lung cancer in men; standardised mortality ratio for bronchitis in women $=0.79$ infant death rate +0.22 standardised mortality ratio for lung cancer in women. In these equations the mean infant death rate was standardised to a value of 100 and adult death rates during 1968-78 were used.
TABLE III-Correlation of causes of death (standardised mortality ratios) in 1968-78 and infant mortality rates from bronchitis and pneumonia in 1921-5 in three geographical groups in men and women

\begin{tabular}{lcccc}
\hline & \multicolumn{4}{c}{ Geographical group } \\
\cline { 2 - 5 } \multicolumn{1}{c}{ Cause of death } & $\begin{array}{c}\text { County boroughs } \\
\text { London boroughs }\end{array}$ & $\begin{array}{c}\text { Urban } \\
\text { areas }\end{array}$ & $\begin{array}{c}\text { Rural } \\
\text { areas }\end{array}$ & $\begin{array}{c}\text { All } \\
\text { areas }\end{array}$ \\
\hline & Men & & & \\
Bronchitis & 0.75 & 0.77 & 0.75 & 0.84 \\
Rheumatic heart disease & 0.48 & 0.63 & 0.53 & 0.61 \\
Pneumococcal pneumonia & 0.26 & 0.42 & 0.36 & 0.41 \\
Lung cancer & 0.46 & 0.23 & 0.04 & 0.61 \\
& & & & \\
Bronchitis & Women & 0.74 & 0.68 & 0.80 \\
Rheumatic heart disease & 0.70 & 0.56 & 0.59 & 0.71 \\
Pneumococcal pneumonia & 0.23 & -0.05 & -0.10 & 0.26 \\
Lung cancer & 0.00 & -0.23 & -0.39 & 0.20 \\
\hline
\end{tabular}

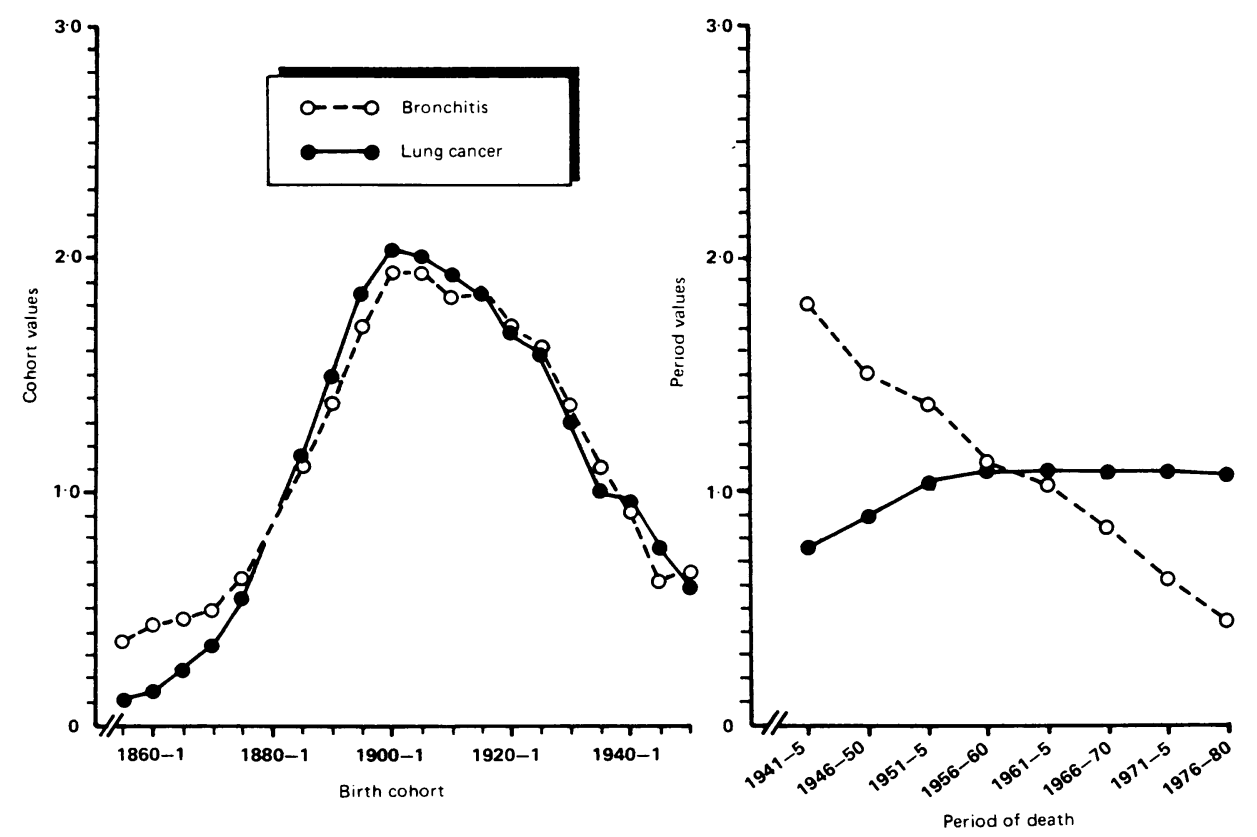

FIG 3-Cohort and period of death values for lung cancer and chronic bronchitis in men aged over 25 in England and Wales during 1941-80.

TABLE II-Correlation of causes of death (standardised mortality ratios) in 1968-78 and infant mortality rates from bronchitis and pneumonia in 1921-5 by age and sex in 212 geographical areas of England and Wales

\begin{tabular}{lccccc}
\hline & \multicolumn{5}{c}{ Age group (years) } \\
\cline { 2 - 6 } \multicolumn{1}{c}{ Cause of death } & $35-44$ & $45-54$ & $55-64$ & $65-74$ & $35-74$ \\
\hline & \multicolumn{5}{c}{ Men } \\
Bronchitis & 0.43 & 0.79 & 0.84 & 0.79 & 0.84 \\
Rheumatic heart disease & 0.50 & 0.54 & 0.49 & 0.25 & 0.61 \\
Pneumococcal pneumonia & 0.27 & 0.37 & 0.40 & 0.36 & 0.41 \\
Lung cancer & 0.46 & 0.68 & 0.62 & 0.48 & 0.61 \\
& & & & & \\
Bronchitis & 0.44 & 0.70 & 0.73 & 0.74 & 0.80 \\
Rheumatic heart disease & 0.65 & 0.71 & 0.57 & 0.46 & 0.71 \\
Pneumococcal pneumonia & 0.19 & 0.30 & 0.21 & 0.18 & 0.26 \\
Lung cancer & 0.46 & 0.49 & 0.19 & -0.09 & 0.20 \\
\hline
\end{tabular}

Figures 3 and 4 show the age specific mortality trends for bronchitis and lung cancer during 1941-80 summarised by birth cohort and period values. The cohort values relate to successive generations born from 1856 to 1951 . Among men they rose to a peak for both diseases in generations born around 1900-5; among women they rose to a later peak in generations born around 1925, again for both diseases. Period values for lung cancer were close to unity for both sexes throughout 1941-80, but for bronchitis they declined steadily, falling fourfold in men and ninefold in women during the 40 years.

\section{Discussion}

There was a close geographical relation between adult mortality from bronchitis and emphysema and past infant mortality from bronchitis and pneumonia (figs 1 and 2). Our analyses were based on adult mortality over 20 years and on the whole of England and Wales divided into the 212 areas used by the Registrar General. The

TABLE IV-Correlation of causes of death (standardised mortality ratios) in 1959-67 and infant mortality rates from bronchitis and pneumonia in 1921-5 in three geographical groups in men and women

\begin{tabular}{lcccc}
\hline & \multicolumn{4}{c}{ Geographical group } \\
\cline { 2 - 5 } \multicolumn{1}{c}{ Cause of death } & $\begin{array}{c}\text { County boroughs }+ \\
\text { London boroughs }\end{array}$ & $\begin{array}{c}\text { Urban } \\
\text { areas }\end{array}$ & $\begin{array}{c}\text { Rural } \\
\text { areas }\end{array}$ & $\begin{array}{c}\text { All } \\
\text { areas }\end{array}$ \\
\hline & Men & & & \\
Bronchitis & 0.69 & 0.73 & 0.67 & 0.80 \\
Rheumatic heart disease & 0.40 & 0.51 & 0.46 & 0.54 \\
Pneumococcal pneumonia & 0.27 & 0.36 & -0.05 & 0.43 \\
Lung cancer & 0.23 & -0.05 & -0.24 & 0.43 \\
& & & & \\
Bronchitis & Women & 0.58 & 0.54 & 0.77 \\
Rheumatic heart disease & 0.70 & 0.60 & 0.52 & 0.68 \\
Pneumococcal pneumonia & 0.56 & 0.21 & -0.03 & 0.31 \\
Lung cancer & 0.29 & -0.25 & -0.51 & 0.11 \\
\hline
\end{tabular}


TABLE V-Correlation of mortality from chronic bronchitis with other causes of death (standardised mortality ratios) during 1968-78 in three geographical groups in men and women

\begin{tabular}{|c|c|c|c|c|}
\hline \multirow[b]{2}{*}{ Cause of death } & \multicolumn{4}{|c|}{ Geographical group } \\
\hline & $\begin{array}{c}\text { County boroughs }+ \\
\text { London boroughs }\end{array}$ & $\begin{array}{l}\text { Urban } \\
\text { areas }\end{array}$ & $\begin{array}{l}\text { Rural } \\
\text { areas }\end{array}$ & $\begin{array}{c}\text { All } \\
\text { areas }\end{array}$ \\
\hline \multicolumn{5}{|c|}{ Men } \\
\hline Rheumatic heart disease & 0.48 & 0.57 & 0.60 & 0.61 \\
\hline Pneumococcal pneumonia & $0 \cdot 20$ & $0 \cdot 27$ & $0 \cdot 24$ & 0.35 \\
\hline Lung cancer & $0 \cdot 47$ & $0 \cdot 30$ & $0 \cdot 40$ & 0.66 \\
\hline $\begin{array}{l}\text { Infant bronchitis and } \\
\text { pneumonia, } 1921-5\end{array}$ & 0.75 & 0.77 & 0.75 & 0.84 \\
\hline \multicolumn{5}{|c|}{ Women } \\
\hline Rheumatic heart disease & 0.63 & 0.48 & 0.64 & $0 \cdot 70$ \\
\hline Pneumococcal pneumonia & $0 \cdot 16$ & $-0 \cdot 12$ & $0 \cdot 17$ & 0.25 \\
\hline Lung cancer & $0 \cdot 12$ & -0.06 & 0.02 & 0.33 \\
\hline $\begin{array}{l}\text { Infant bronchitis and } \\
\text { pneumonia, 1921-5 }\end{array}$ & 0.70 & 0.74 & 0.68 & $0 \cdot 80$ \\
\hline
\end{tabular}

that determinants of chronic bronchitis act in early life. Fo example, among British born men who migrated to the Unit States the prevalence of chronic bronchitis, after allowing for smoking habits, was higher than among migrants from Norway. was higher among those born in urban areas of Britain and wā unrelated to age at migration. ${ }^{2}$

Follow up studies of infants and young children who have hæed bronchiolitis have shown persisting abnormalities of pulmonat function. ${ }^{7.9}$ For example, among 130 children in Tyneside reviewee 10 years after admission to hospital in infancy with respirato $\vec{y}$ syncytial virus infection (the most common cause of bronchiolitis there was a threefold increase in bronchial lability compared wif controls. ${ }^{9}$ A study of 7 year old children suggested that bronch reactivity and persisting abnormalities of ventilatory function $m$ 需 result after acute lower respiratory tract infection in infancy git any site-that is, bronchitis, bronchiolitis, or pneumonia. ${ }^{10}$ The simplest interpretation of these observations is that infection of t

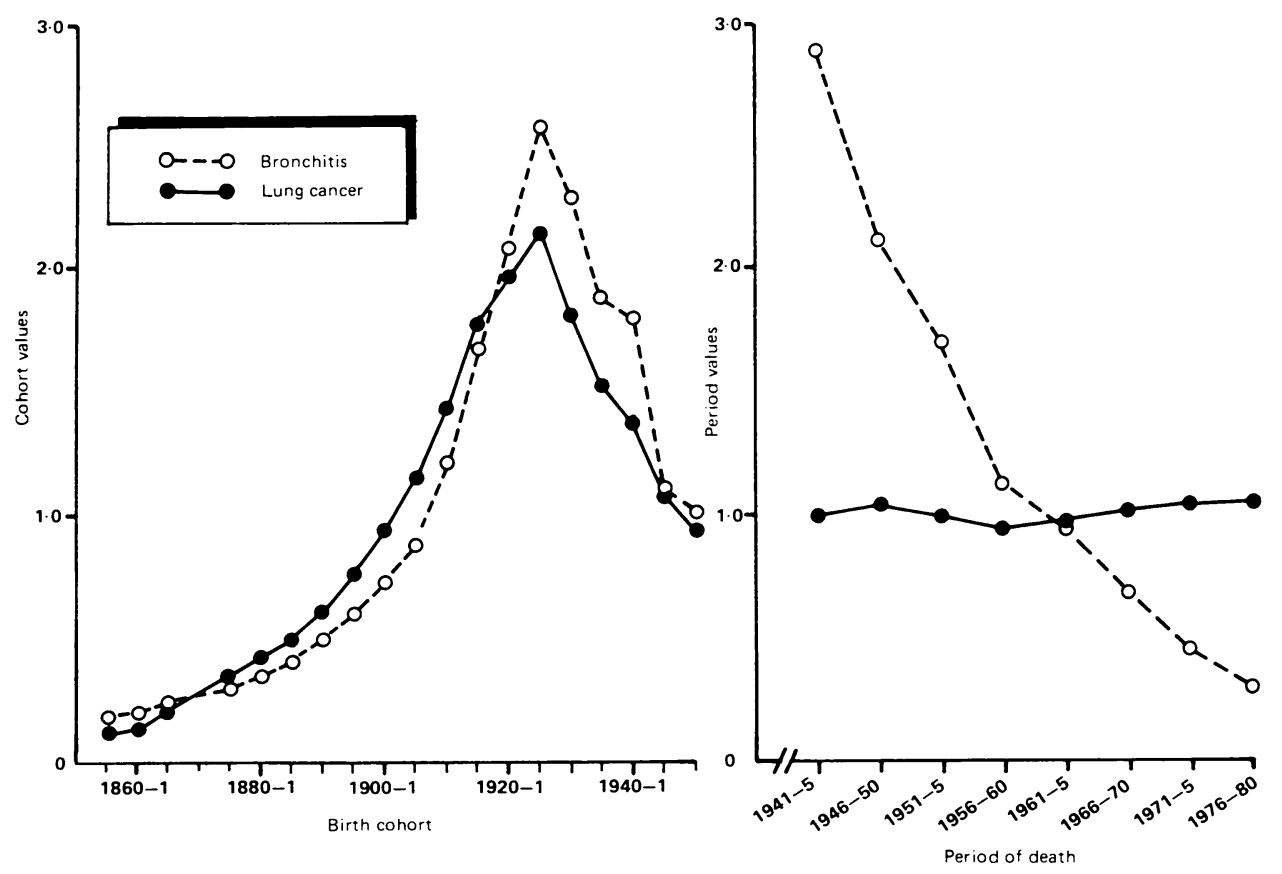

FIG 4 Cohort and period of death values for lung cancer and chronic bronchitis in women aged over 25 in England and Wales during 1941-80.

correlations between mortality from bronchitis during 1959-78 and infant respiratory mortality during 1921-5 were consistent in both sexes and at all ages in the different geographical groups and throughout the 20 years (tables II-IV). They were remarkably high, particularly in view of known inaccuracies in death certification.

From detailed studies of death certification and results of prevalence surveys in Britain it is reasonable to conclude that geographical differences in mortality certified as due to chronic bronchitis and emphysema reflect differences in the prevalence of these diseases. ${ }^{2}$

Past infant respiratory mortality correlated more closely with current adult mortality from bronchitis than it did with any other common cause of death, or with any other cause of past infant death, or with past mortality from bronchitis at all other ages (table I). No other cause of infant death correlated more closely with bronchitis, though the correlation with measles was similarly high. Adult bronchitis correlated more closely with rheumatic heart disease than with any other leading cause of adult death, but the coefficients were below those with past infant respiratory mortality (table V).

A pointer to the possible role of childhood respiratory infection in the causation of adult chronic bronchitis comes from the broad similarity in the international geography and time trends of respiratory disease at different ages. ${ }^{5}$ Migrant studies also suggest lung during the period of rapid growth in infancy has deleterio effects on lung function which persist into childhood. An alternatige explanation is that influences such as atopy render some infan more susceptible to symptomatic lower respiratory tract infection and independently determine respiratory abnormalities in lat childhood. While this cannot be discounted, recent studies have nØ̊ shown a relation between atopy and lower respiratory infection children. ${ }^{19} 20$

In a national sample of 3899 children born in 1946 and followe up to the age of 20 those with a history of one or more low respiratory tract infections before 2 years of age had a higher reported prevalence of cough during the day or at night in the winter. " This association strengthened after follow up to 25 years There is, however, no direct evidence linking respiratory infection in early childhood with chronic bronchitis in adults.

Arguably the geographical relation between infant mortality fro respiratory infection and adult mortality from bronchitis depen $\$$ on persistence over the years of geographical differences in the environment related to respiratory disease at all ages. Air tempera ture is a possible example. ${ }^{21}$ Several determinants of bronchitio, however, act only at certain ages. ${ }^{22}$ The risk of infant respirato 8 infection may be reduced by breast feeding ${ }^{2023}$ and is increased overcrowding, the number and age of other siblings, their presen 
in the same room at night, respiratory infection among them, and parental smoking. ${ }^{2426}$ Domestic air pollution may also have an effect on infant respiratory infection, though the balance of evidence suggests that this is small. ${ }^{26}$

Among adults cigarette smoking is the main known risk factor. ${ }^{3}$ Mortality from lung cancer, however, did not correlate consistently with infant respiratory mortality (tables II-IV). This suggests that the geography of smoking differs from that of the determinants of respiratory disease in early childhood. Despite the influence of smoking on adult bronchitis the urban-rural and social class gradients of infant and adult mortality were strikingly similar. When standardised to a value of 100 for England and Wales infant respiratory mortality during 1921-5 declined from 125 in the county boroughs to 98 in the London boroughs, 93 in urban areas, and 70 in rural areas. The corresponding figures for adult mortality during 1968-78 were $122,113,96$, and 74 . Similarly the standardised mortality ratios for infants in 1921 rose progressively from 21 in social class I to 131 in social class $\mathrm{V}$, while standardised mortality ratios for adults in 1970-2 rose from 36 to 188 .

The close geographical relation between bronchitis and chronic rheumatic heart disease, in contrast with the low correlations with pneumococcal pneumonia (tables II-IV), is further evidence for a strong link between bronchitis and past respiratory infection. Most deaths from bronchitis during 1968-78 at ages 35-74 years occurred among people born before 1921-5, the earliest years for which cause specific infant mortality data were published. Total postneonatal death rates, however, are available from $1911^{14}$ and may be used as a proxy for respiratory deaths in infants. Respiratory infection is the main cause of postneonatal mortality and was closely correlated with it geographically during $1921-5(r=0.94)$. The correlation coefficients between postneonatal mortality and adult mortality from bronchitis during 1968-78 in both sexes were the same ( $r=$ 0.83 ) for postneonatal rates throughout $1911-20$ as for 1921-5. This is consistent with a relation between adult bronchitis and respiratory infection in early childhood. Follow up studies of children suggest that this relation is determined mainly in infancy.

We conclude that the close geographical relation between infant mortality from respiratory infection and adult mortality from bronchitis provides strong evidence of a direct causal link between lower respiratory infection in early childhood and chronic bronchitis. The regression equations of adult mortality from bronchitis in relation to deaths in infants and from lung cancer may be interpreted as showing the relative importance of early childhood infection and cigarette smoking in determining the prevalence of the disease. They suggest that in both men and women smoking is subordinate.

Figures 3 and 4 show that the bronchitis time trends may be partitioned into two components. The cohort component corresponds remarkably closely to that found for lung cancer and may be attributed to the different smoking habits of successive generations of men and women. The other component, described by the steeply declining period values, indicates that the age specific rates had fallen progressively since 1941 . This pattern is quite different from that found for lung cancer, for which the period values were almost constant, and suggests another cause. The decline in infant bronchitis and pneumonia in the early decades of this century ${ }^{22}$ may have determined the subsequent fall in age specific mortality from bronchitis in adults. The steeper fall among women than men is consistent with the lesser contribution of smoking to their mortality. Improved treatment after the advent of antibiotics may have contributed to the decline in both sexes.

The Clean Air Act 1956 was not followed by a change in the rate of decline. This is evidence that chronic air pollution in adult life, as opposed to short episodes of high pollution, may be a less important cause of mortality from bronchitis than previously supposed. A survey of respiratory symptoms in a sample of British adults showed that in the absence of cigarette smoking the influence of air pollution was small. ${ }^{3}$ There is suggestive evidence that children exposed to high levels of air pollution may have an increased risk of serious respiratory disease, but this is not conclusive. One inconsistency is the high rates for respiratory disease recorded in south Wales at a time when air pollution was relatively low. ${ }^{28} 29$
We interpret our findings as strong support for the hypothesis that pulmonary infection during infancy may have persisting effects and cause chronic bronchitis in adult life. Our results throw no light on the nature or site of pulmonary infection except in so far as adult mortality from bronchitis is related to infant bronchitis and pneumonia, to measles, but not to whooping cough. Recent findings have shown that apart from bronchiectasis, which is no longer common, whooping cough is not followed by persisting abnormalities of lung function in childhood. ${ }^{30} 31$

We have previously suggested that the geographical distribution of ischaemic heart disease in England and Wales reflects social conditions in the early years of the century that adversely affected childhood nutrition. ${ }^{13}$ We now conclude that the high mortality from chronic bronchitis in England and Wales, especially in the towns, is another legacy of poor social conditions which led to high rates of respiratory infection in young children. Particular adverse influences which have been implicated include abandonment of breast feeding, inadequate housing, large family size, and overcrowding in the home.

We thank our colleagues in the MRC Environmental Epidemiology Unit, in particular Mr Paul Winter, who helped with the computing; Mrs Shirley Simmonds and Miss Rosemarie Kirby, who abstracted data; and Mrs Bridget Wilde, who typed the manuscript.

\section{References}

1 Holland WW, Gilderdale S. Epidemiology of chronic bronchitis. In: Scadding JG, Cumming G, Thurlbeck WM, eds. Scientific foundations of respiratory medicine. London: Heinemann, 1981:18-29.

2 Reid DD, Fletcher CM. International studies in chronic respiratory disease. Br Med Bull 1971:27:59-64

3 Lambert PM, Reid DD. Smoking, air pollution, and bronchitis in Britain. Lancet 1970;i:853-7.

4 Orie NGM, Sluiter HJ, eds. Bronchitis-an international symposium. Groningen, the Netherlands: Assen Royal Vengorium, 1961

5 Reid DD. The beginnings of bronchitis. Proceedings of the Royal Society of Medicine 1969;62: $311-6$

6 Holland WW, Hali T, Bennett AE, Elliott A. Factors influencing the onset of chronic respiratory disease. BrMed $\mathcal{O}$ 1969;ii:205-8.

7 Kattan M, Keens TG, Lapierre JG, Levison H, Bryan AC, Reilly BJ. Pulmonary function abnormalities in symptom-free children after bronchiolitis. Pediatrics 1977;59:683-8.

8 Gurwitz D, Mindorff C, Levison H. Increased incidence of bronchial reactivity in children with history of bronchiolitis. Pediatrics 1981;98:551-5.

9 Pullan CR, Hey EN. Wheezing, asthma, and pulmonary dysfunction 10 years after infection with respiratory syncytial virus in infancy. Br Med f 1982;284: 1665-9.

10 Mok JYQ, Simpson H. Outcome for acute bronchitis, bronchiolitis, and pneumonia in infancy. Arch Dis Child 1984;59:306-9.

11 Colley JRT, Douglas JWB, Reid DD. Respiratory disease in young adults: influence of early childhood lower respiratory tract illness, social class, air pollution, and smoking. $\mathrm{Br} \mathrm{Med} \mathcal{J}$ 1973;iii:195-8.

12 Kiernan KE, Colley JRT, Douglas JWB, Reid DD. Chronic cough in young adults in relation to smoking habits, childhood environment and chest illness. Respiration 1976;33:236-44.

13 Barker DJP, Osmond C. Infant mortality, childhood nutrition, and ischaemic heart disease in England and Wales. Lancet 1986; i: 1077-81.

14 Registrar General. Statistical review of England and Wales. Pan I: tables, medical. London: HMSO, 1911 et seq.

15 Woolf B. Studies on infant mortality: part II. Social aetiology of stillbirths and infant deaths in county boroughs of England and Wales. British fournal of Social Medicine 1947;2:73-125.

16 Osmond C, Gardner MJ. Age, period and cohort models applied to cancer mortality rates. Statistics in Medicine 1982;1:245-59.

17 Gardner MJ, Winter PD, Taylor CP, Acheson ED. Atlas of cancer morality in England and Wales 1968-78. Chichester: Wiley, 1983

18 Gardner MJ, Winter PD, Barker DJP. Atlas of mortality from selected diseases in England and Wales 1968-78. Chichester: Wiley, 1984

19 Mok JYQ, Simpson H. Symptoms, atopy, and bronchial reactivity after lower respiratory infection in infancy. Arch Dis Child 1984:59-299-305.

20 Sims DG, Gardner PS, Weightman D, Turner MW, Soothill JF. Atopy does not predispose to RSV bronchiolitis or postbronchiolitic wheezing. Br Med J 1981;282:2086-8.

21 Boyd JT. Climate, air pollution and mortality. British fournal of Preventive and Social Medicine 1960;14:123-35.

22 Colley JRT. Respiratory disease in childhood. Br Med Bull 1971;27:9-14.

23 Downham MAPS, Scott R, Sims DG, Webb JKG, Gardner PS. Breast feeding protects against respiratory syncytial virus infections. Br Med J 1976;ii:274-6.

24 Leeder SR, Corkhill R, Irwig LM, Holland WW, Colley JRT. Influence of family factors on the incidence of lower respiratory illness during the first year of life. British fournal of Preventive and Social Medicine 1976;30:203-12.

25 Pullan CR, Toms GL, Martin AJ, Gardner PS, Webb JKG, Appleton DR. Breast feeding and respiratory syncytial virus infection. $B r$ Med $\mathcal{J}$ 1980;281:1034-8.

26 Ogston SA, Florey $\mathrm{C}$ du V, Walker CHM. The Tayside infant morbidity and mortality study: effect on health of using gas for cooking. Br Med f 1985;290:957-60.

27 Registrar General. Decennial supplement, occupational mortality, England and Wales 1921, 1970-2. London: HMSO, 1927, 1978.

28 Colley JRT, Reid DD. Urban and social origins of childhood bronchitis in England and Wales. Br Med f 1970;ii:213-7.

29 Royal College of Physicians of London. Air pollution and health. London: Pitmañ 1970.

30 Johnston IDA, Anderson HR, Lambert HP, Patel S. Respiratory morbidity and lung function after whooping cough. Lancet 1983;ii: 1104-8.

31 Swansea Research Unit of the Royal College of General Practitioners. Respiratory sequelae of whooping cough. Br Med f 1985;290: 1937-40.

(Accepted 20 August 1986 